\title{
Весна Крчмар
}

\section{Горски вијенаи као прва позоришна представа у Новом Саду 1902. године}

UDC 821.163.41-13.09 Petrović Njegoš P. : 792.2.02(497.113 Novi Sad)"1902"

Апстракт. Тема овог рада јесте Горски вијенаи изведен као прва позоришна представа на сцени Српског народног позоришта у Новом Саду 1902. године. ПостојепокушајифрагментарногизвођењаГорскогвијения 1896, 1897, 1890. године. Занимљиво је да је Радоје Домановић са својим ученицима у Врању приказивао Горски вијенаи. Поводом педесетогодишњице од смрти Петра Петровића Његоша приказан је Горски вијенаи као целовечерња представа. Бесмртно дело великог песника за сцену је припремио Антоније Хаџић. Пролог је написао песник др Лаза Костић, а Апотеозу као епилог је написао песник Јован Живојиновић. Музику је компоновао и приредио Исидор Бајић. Цео ток припреме представе, извођења, рецепције, гостовања представе у Сомбору пратимо преко првог позоришног листа Позориште, које је излазило у издању најстаријег професионалног театра на овим просторима. Основне дилеме које постоје код поставке Горског вијенца, да ли је то еп или драма, на задивљујуће високом теоријском нивоу објашњава Тихомир Остојић у једном од текстова који претходе свечаном извођењу. О сваком извођењу пише се позоришна критика, па у листу Позориште пратимо критику Јована Храниловића, Милана Савића, критику пренету из Vienca. Захваљујући ревносном хроничару позоришног живота, какав је био лист Позориште, пратимо и оду коју је Лаза Костић спевао Антонију Хаџићу на гостовању представе у Сомбору.

Кључне речи: позоришна представа, еп, драма, Горски вијенаи, лист Позориште, позоришна критика

У издвојеном сегменту посматрања првог извођења представе Горски вијенаи, у Српском народном позоришту пратимо значај постојања позоришних часописа, добро праћен ток припремања представе и даље, њену рецепцију. Примећујемо 
како је изгледала позоришна критика почетком двадесетог века. Позоришну критику су писали најзначајнији књижевни посленици, преводиоци, добри познаваоци театра. То је показатељ да је у позоришту, позоришној уметности тренутка, неопходно бележити, записивати, уметнички позоришни чин преводити у уметност писане речи. Само оно што је записано може постати вечно.

Поводом педесетогодишњице од смрти Српско народно позориште се одлучило да прикаже "то бесмртно дело великога песника српског, онако, као што га је за позорницу удесио А. Хаџић. То ће бити свечана, али уједно и последња представа у овогодишњој позоришној сезони у Новом Саду. Пролог за Горски вијенаи написао је наш песник др Лаза Костић, а Апотеозу као епилог наш песник Ј. Живојиновић. Музику за Горски вијенац зготовио је наш млади компониста Иса Бајић, професор певања на овдашњој великој гимназији српској: Горски вијенаи није још до сад приказан ни на једној позорници српској”. (Позориште, 1902: 11).

Тако бележи најстарији позоришни лист на Балкану. Захваљујући сачуваним примерцима Позоришта ми смо у могућности да реконструишемо, условно речено, како је изгледала прва целовечерња представа Горског вијенца. Тог тешког посла адаптације за сцену прихватио се Антоније Хаџић који је припремао драмске текстове за сценске услове играња позоришних представа Српског народног позоришта. Такође је био и уредник дневног позоришног листа Позориште пуних тридесет седам година.

Велики песник, преводилац, драмски писац, позоришни критичар, пријатељ Српског народног позоришта Лаза Костић написао је Апотеозу за Горски вијенаи у којој је посебно ефектан био крај који је говорила Милка Марковић.

"Док на ту земљу ови стоји кам.

најцрњи враг је Србин себи сам!” (Милан Савић,1902: 74)

У сачуваном листу поводом свечане представе ${ }^{1}$ Горског вијенца оживљавамо

1 53. представа у Дунђерсковом позоришту. Ван претплате.

Свечана представа у славу и спомен посмртне педесетогодишњице Петра Петровића Његоша У Новом Саду, у понедељак, 26. јануара (8. фебруара) 1902.

По други пут: ГОРСКИ ВИЈЕНАЦ. Историјски догађај при свршетку XVII века, саставио Петар Петровић Његуш, владика црногорски. За позорницу у два раздела удесио А. Хаџић, а музика од Исе Бајића. Редитељ: Спасић. Особе: Владика Данило - Ружић; Игуман Стефан Лукић; Јанко Бурашковић, сердар - Ботић; Радоња, сердар - Слука; Иван Петровић, сердар - Шикопарија; Вукота, сердар - Стефановић; Кнез Раде, брат владике Данила - Душановић; Кнез Роган - Стојановић; Кнез Јанко - Николић; Војвода Драшко - Добриновић; Војвода Батрић - Виловац; Обрад - Матејић; Вук Мићуновић - Спасић; Вук Мандушић - Илкић; Поп Мићо - Бакаловић; Сестра Батрићева - Д. Спасићка; Хаџи-Али Медовић, кадија - Марковић; Скендер-Ага - Динић; Мустај кадија - Барјактаревић; Рацал Осман ***

Баба - М. Тодосићка; Прва - С. Бакаловићка; Друга - Д. Матејићка; Трећа - Д. Васиљевићка; Четврта - 3. Добриновићка; Пета - Д. Николићка; Шеста - К. Виловчевица. Hарод.

Пре тога: Пролог за «Горски вијенащ» Написао др Лаза Костић, музика од И. Бајића 
глумачку поделу, време одржавања представе, као и њено трајање.

Тихомир Остојић пише у свечаном броју поводом извођења Горског вијенцза и у свом студиозном образложењу прави разлику између драме и епа. Та дилема била је посебно присутна у текстовима поводом следеће представе Горског вијенца у Народном позоришту 1951. у адаптацији и режији Раше Плаовића.

Тихомир Остојић наглашава да је било потребно да прође више од пола века од када се штампало најбоље дело Његошево и да га тек тада видимо у целости, први пут на позорници. Фрагментарних покушаја извођења Горског вијенциа, углавном у оквиру школских приредби, било је више. Једно од првих, везује се за Радоја Домановића, који је знао напамет готово цео Горски вијенаи, а одломке је приредио са ученицима у Гимназији у Врању 1896. године. Да је Горски вијенаи једна од најзанимљивијих књига српских, показује податак да је већ 13 - 14 пута прештампавано.

Тихомир Остојић се пита:

“Зар се збиља толика покољења задовољише само тим, да оне дивне стихове, ону чисту појезију, оне вечите мисли, ону дубоку философију само из књиге читају, а нигда не пожелеше да их, лепо наговорене, и чују? Зар досле никоме не заиска срце, да не само у мислима, него у позоришној илузији види владику Данила, Мићуновића, игумана Стефана, Драшка и толике друге миле ликове? Кад се приказиваху на нашим позорницама старије драме, о којима нико не рече ни да су добре, него се изношаху на даске цигло због пијетета према старини, како да се нико не маши за најбољим делом наше књижевности?” (Остојић, 1902: 56).

Посебна прилика је била педесетогодишњица песникове смрти, која је иницирала упризорење Горског вијенца на сцени. Сада ће многи, који нису читали Горски вијенаи, имати прилику да га виде на сцени и чују мудре речи у интерпретацији глумаца.

Велике су тешкоће које се отварају у реализацији Горског вијенца на сцени. Тешкоће проистичу из његовог необичног облика, јер многи критичари нису били у стању да одреде којој песничкој врсти припада: драми или епу. То није драма као што су, на пример: Костићева, Трифковићева, или Шекспирова... Има драматски облик, закључује да је то “и сам песник хтео, да напише драму” (Остојић, 1902:

Особе: Пролог - М. Марковићка

На завршетку: Апотеоза као епилог за «Горски вијенац» Написао Јован Живојновић, музика од Исе Бајића. Особе: Вила - Т. Лукићка; Милош Обилић - Васиљевић; Владика Данило - Ружић; Вук Мићуновић - Спасић; Црногораи - Николић. Народ. Почетак тачно у $7_{1 / 2}$ а свршетак у $10_{1 / 2}$ caxama 
57). У драми “не приказује догађаје и људе сам писац, него се догађаји приказују у дијалозима и монолозима, које говоре лица што суделују у догађају, те тако из њихова разговора познамо и њих, и видимо очима радњу, добивамо непосредну слику догађаја и илузију живота - то има и у Горском вијениу. Али, поред тога, нечега у њему недостаје, што смо свикли да гледамо и да нађемо у обичним драмама" (Остојић, 1902: 58).

Његош је своје дело назвао "Историческо собитије при свршетку XVII вијека". То значи да је нека врста историјске драме. "У њему се приказује један крвав догађај из историје црногорске: како су за владике Данила једнога Бадњега Дна, Црногорци истребили потурице из Црне Горе” (Остојић, 1902: 58).

Појам историјске драме не треба узимати у дословном значењу, јер, иако су лица из прошлости, скоро сва позната у историји, или бар у народним јуначким песмама, "али Његош није приказао Црногорце од пре двеста година, него Црногорце својега времена, дакле је у многоме изменио карактере, а није ни догађаје оставио онако, како их је у својим изворима нашао. Уопће, њему није стало до историјске тачности и верности. Њему је друго нешто лебдело пред очима. Он гледа у истрази потурица почетак борбе црногорске за слободу; још више, њему је ова борба на Цетињу и око Цетиња први знак, да се буди Српство, које је закопано још 'на Косову у једну гробницу'. То је, ако се тако схвати, онда врло важан чин, и песник је предузео да тај први знак живота српског, после косовске гробнице, што већма прослави, јунаке, који су започели борбу с Турцима, да дигне у звезде, јер је њиховим прегалаштвом, 'слобода дивно васкрснула из гробова наших ђедова', јер је споменик њихова јунаштва 'Црна Гора и њена слобода'. Не ради се ту, дакле, о том, да се, колико се може у драми, са историјском верношћу прикаже један догађај при крају XVII века, него се хоће да се прославе јунаци, који су први устали да се боре за слободу. Песник је у први мах овом делу дао према томе и име, које ће ту страну његову несумњиво истакнути; назвао га је 'Извијање Искре', 'Извита Искра' тј. тада је први пут севнула искра слободе у тами ропства, у којој је од два три века чамао српски народ, (како то име тумачи др Решетар)" (Остојић, 1902: 58).

Највише недоумица код тадашњег гледаоца што у Горском вијениу нема пуне, живе радње, која се, згодно заметнула, све даље природно развија, долази до кулминације и онда иде ка своме завршетку. Уместо тога добијамо слике, призоре, који приказују поједине моменте радње. И колико би радња сама од себе, кренула, развијала се, сам је Његош све више задржава, прекида. Али су поједини призори и слике, ненадмашни песнички облици, "сваки за себе је један драги камен; само нема чврстога оквира, који би их стегнуо у један целокупан украс" (Остојић, 1902). У томе аутор текста у Позоришту види разлог зашто се до тада није Горски вијенаи приказивао на позорници. Чини се да је Његошу стало највише да једну 
ситуацију употреби, да је експлоатише, “да се у њој изговори, да нам нешто лепо исприча на уста које личности, да нас осећајима, већином својим, исказаним у савршеним стиховима, раздрага, да нас мислима и идејама, које она ситуација избаци, понесе у недогледне висине и даљине васељене, и ако му је то пошло за руком, као што увек јесте, онда је амбиција његова генија задовољена, а за даљи ток радње се не брине, него чека опет згодан тренутак” (Остојић, 1902:58).

У Горском вијенщу нема драматске радње, али исто тако му недостају и драматски јунаци. Ако доведемо то двоје у везу, логично је: драматске радње нема, јер нема развијених карактера. Слабо индивидуалисање и недраматичност лица у Горском вијениу је одбијало управе наших позорница од тог комада.

Вешта игра је дала много живота појединим лицима у Горском вијениу, јер је то дело великог песника, који иде својим путем, који се не спушта својим конвенционалним формама, јер се гледалац мора прилагодити песнику на његов начин приказивања, да се ослободимо конвенционалног, и тек тада ћемо, “с песником узлетети

'у весело царство појезије

како росне свијетле капљице

уз веселе зраке на небеса"” (Остојић, 1902: 59).

О свечаној представи Горског вијенцуа 26. јануара 1902. године је писано с великим интересовањем и у Позоришту се преноси поздрав црногорског кнеза Николе I:

"Велико одушевљење изазвао је брзојавни поздрав кнеза црногорског Николе I .. управљен на А. Хаџића ове садржине:

'Пуно вамзахваљујемнасаопштењу, даће седанаспрви путпредстављати Горски вијенац мога великога стрица. Увјерен сам, да ће вашом вјештином удешен за позорницу успјети. Жалим, што не могу бити присутан, да аплаудирам генију српске Спарте на позорници српске Атине.

Никола."” (Позориште, 1902: 75-76)

Јован Храниловић био је један од првих позоришних критичара који је писао поводом премијере Горског вијенца у Српском народном позоришту. Посебну заслугу за тај историјски позоришни догађај приписује Антонију Хаџићу и музици Исе Бајића. Сматра да је Немцима било потребно јако много времена да на сцену поставе Гетеовог генијалног Фауста. Сматра да је још више храбрости требало да се "величанствени песмотвор ђенијалног владике Рада приреди за позорницу. Тај 
песмотвор нема много драмскога елемента у себи те доиста ђенијалном песнику није ни на крај памети било, да напише драмски комад. Он је имао својих разлога, да даде Горском вијениу форму, у каковој нам је познат, али на драму није мислио, а сигурно није ни слутио, да ће тај његов јединствени песмотвор са позорнице одушевљавати гледаоце" (Храниловић, 1902: 73).

Затим се опредељује за аутентичан запис са представе:

"Намера ми је тек, да с неколико речи забележим приказ Горскога вијенца на новосадској позорници дне 26. јануара (8. фебруара) о. г. у преудезби А. Хаџића.

Госп. Хаџић прихватио се тешка посла. Требало је ту изабрати, изоставити, скалупити у целину, удесити какову такову градуацију и драмску акцију, а све то ваљало је извести тако, да остане нетакнута основна структура и концепција са свима особинама тога песмотвора. Требало је маркирати протагонисту, истакнути контрастику, наћи згодан почетак и завршетак једном и другом делу, удесити размере озбиљнога и веселога елемента, диференцирати поједина лица и пронаћи згодан начин за рецитацију величанствене поезије у коровима, а све то тако, да и онај, ко није тога песмотвора читао, узмогне себи створити о њему прави суд и уживати у његовим необичним красотама.

Је ли у том г. А. Хаџић успео? Ја мислим, да јесте, а да је доиста тако, доказује диспозиција публике, која је опетовано давала одушке свом задовољству и одушевљењу.

Глумци су били проникнути уверењем, да се овај пут ради о достојном приказу највеличанственијега песмотвора, што га је икада српски ђеније испевао, те су управо с пијететом настојали, да Горски вијенаи засја: у што сјајнијем сјају на позорници. Како су улоге биле добро пораздељене, био је приказ такав, да служи на част честитој нашој дружини.

Већ сампролог, што гаје испевао др Лаза Костић а лепо издекламовала гђа Милка Марковићка, занео је публику, која је озбиљном достојанственошћу слушала јединствене стихове, пуне ђенијалних сентенција, великога владике песника, какових је мало и у светској литератури испевано.

Још стојећи под утиском приказа Горскога вијенща, публика је истим одушевљењем слушала и прекрасни епилог и апотеозу из пера Јована Живојиновића, те је раздрагана, одушевљена, одала устајањем са седишта 
пошту ђенију славнога владике песника, понесавши у души неизбрисиви утисак ђенијалних његових стихова и слика, обасјаним светлилом његова ђенија.” (Храниловић, 1902: 73-74).

Милан Савић је писао о другој² представи Горског вијенща 28. јануара 1902. У уводном делу он наглашава да нема намеру да пише приказ извођења ремекдела, јер је то већ учињено. Он региструје неке специфичности сценског извођења друге представе Горског вијенияа.

"Било је заиста смело, јуначко предузеће, изнети на позорницу разговоре и причања црногорских владара у Горском вијениу. У самом делу не даје ништа повода, што би кога навело, да целину драматизира. Можда поједине призоре, као извештај о јуначком чину Мартиновићậ. Но кад би се когод и подухватио, да тај извештај драматизира, морао би написати сасвим ново дело, у ком би Горски вијенаи имао врло мало удела. И онда не би био Горски вијенаи изнесен на позорницу нити бисмо имали прилике с л у ш а т и несамртне мисли и стихове великога песника српског, ни г л е д а т и, како су све то могли, у замисли песниковој, тадашњи црногорски главари казати. Тако је онда то велико песничко дело изнесено пред нас у конкретном облику. Ми сад имамо од прилике појма, како се у њему призори могли збити - а то све имамо да захвалимо, од срца да захвалимо подузетној и умешној руци госп. А. Хаџића.

Наша публика, која је дупком испунила позориште, показала је одмах неко свечано расположење. Знала је, да се ту неће ни насмејати ни растужити, него једино да има одати поштовање песничком генију. То свечано расположење трајало је све до свршетка - ми се клањамо публици, свесној положаја и позива свог тога вечера.

2 55. представа у Дунђерсковом позоришту. Ван претплате. Свечана представа у славу и спомен посмртне педесетогодишњице Петра Петровића Његоша. Последња представа а за народ с обаљеним ценама. У Новом Саду, у понедељак, 28. јануара (10. фебруара) 1902. По други пут: ГОРСКИ ВИЈЕНАЦ. Историјски догађај при свршетку XVII века, саставио Петар Петровић Његуш, владика црногорски. За позорницу у два раздела удесио А. Хаџић, а музика од Исе Бајића. Редитељ: Спасић.

[Подела је углавном иста као код премијерног извођена, па је не преносимо.]

На завршетку: Апотеоза као епилог за «Горски вијенац». Написао Јован Живојновић, музика од Исе Бајића. Особе: Вила - Т. Лукићка; Милош Обилић - Васиљевић; Владика Данило - Ружић; Вук Мићуновић - Спасић; Црногорач - Николић. Народ. Свирачки збор ц. и кр. 70. пешачке пуковније петроварадинске свираће ове комаде: 1. Српска зора. 2. Чижек: Из српске шуме и утрине. Фантазија. 3. Чижек: Српске песме. Потпури. Почетак тачно у $7_{1 / 2}$ а свршетак у $10_{1 / 2}$ сахата 
Разуме се по себи, да овим редовима није задатак приказати Горски вијенаи. То је учињено већ од позваних па и у овом листу. Ми можемо толико рећи, да је госп. А. Хаџић учинио све што се учинити могло. Па кад се дело већ није дало драматизовати, госп. Хаџић је срећном руком положио претежност у сценични приказ, у живописно групирање особа, у изношењу женскога (а не мушкога) хора, у карактеристичне маске, говоре, гесте и мимике. Што је тога ради приличан део Горскога вијенца изоставио, разбацане призоре стопио, може му се само у прилог рачунати. Ни Шекспир се не износи цео, ни онакав какав је, на позорницу.

Од великог утиска беше Пролог од Лазе Костића, који је гђа Милка Марковићка величанствено приказла. Завршне речи:

Док на ту земљу ови стоји кам.

најирњи враг је Србин себи сам!

можемо само тако тумачити: да ће Србин у в е к и свагда бити себи најцрњи враг, јер ће и Ловћен на свом месту у в е к и свагда бити и остати. Ко ће га и покренути?! Изглед жалостан, ал' - тако је. Песимистично пророштво песниково требало би да нас упозори....

$\mathrm{C}$ већим спољашњим, театралним ефектом приказана је Апотеоза као епилог од Јована Живојиновића. Срећна је мисао била пишчева да приказ унесе у цркву владичину на Ловћен. Вилу је приказала гђа Тинка Лукићка с пуно заноса. Глумац (Душановић), који је приказао владику песника, сасвим је лепо погодио маску његову.

\section{|.../}

Приказ је био да не мож’ бољи бити. То констатујемо врло радо, па ако се који глумац јаче истакао, било је случајно у улози му. Ружић у масци владике Данила, Лукић (игуман Стефан), Спасић (Вук Мићуновић), Николић (кнез Јанко), Виловац (Мартиновић), Бакаловић (поп Мићо) и већ Добриновић (војвода Драшко) па и остали кнезови и војводе, даље Спасићка (сестра Батрићева), Тодосићка (баба) и свака коловођица - све је то ишло складно а у служби великога песника српског. Слава му!

Публика наша раздрагана добрим, складним приказом Горског вијенщза бурно је изазвала на свршетку представе г. Хаџића, који је на послетку изишао на позорницу, да захвали публици то одликовање” (Савић, 1902: 74-75). 
У Позоришту су се помно регистровале све критике које су се појавиле поводом извођења Горског вијения. Тако се преноси и критика из Vienca.

“Vienac у свом 12. броју од 20. марта о.г. доноси о приказу 'Горског вијенца' на нашој позорници ову рецензију: ...

Његошу није очевидно било ни на крај памети, да напише драмско дјело, нити је уопће у њега било драмске жице. Изабрао је у Горском вијениу форму разговора међу владиком и црногорским војводама, да му пјесмотвор не буде монотон и да избјегне вјечно опетовање ријечи: 'Сада проговори тај и тај војвода'. Горски вијенаи је пун управо сјајне лирике, али драмскога елемента нема у њему ни за лијек. Када су се ипак неки прихваћали посла, да приреде барем неке одломке Горског вијениа за позорницу, било им је до посљедних слика, било им је до тога да се с љепотама Његошева пјесмотвора упознају и они, који се тешко одлучују, да га у цијелости прочитају. Заслужни српски књижевник, вјешт приређивач многих иначе у првобитној форми за позорницу незгодних пјесмотвора Антоније Хаџић, прихватио се тешка посла, да најљепши Његошев пјесмотвор приреди у цијелости за позорницу.

Г. А. Хаџић раздијелио је сав пјесмотвор у два једнака велика дијела. У првом се спремају војводе на истрагу (уништење) Турака у Црној Гори, - у другом дијелу приповиједа војвода Драшко своје доживљаје у Мљецима, те јављају Мартиновићи владици Данилу и војводама, да су на сам бадњак посмицали Турке. Неки критичари мисле, да је превише тога изостављено, да је у приредби за позорницу премало драматике и да је незгодно, што корове извађају женске. Али да је Горски вијенаи приређен за позорницу према свима прописима драмске технике, морало би још више тога изостати, а не би било могуће ни из далека сачувати првобитну концепцију, колорит и карактеристику Његошева пјесниковања.

Хаџићу је за право било до тога, да даде прилике и онима, који нису читали највеличајнији Његошев пјесмотвор, да уживају његове красоте. За то је оставио у њему све непромијењено само што је изоставио оно, што је мање потребно за разумијевање темељне идеје.

Вањском успијеху Горског вијенщяа на новосадској позорници припомогао је много прослов дра Лазе Костића, “апотеоза и епилог Јована Живојиновића и глазбена пратња Исе Бајића". 
Колико је Позориште, као први позоришни лист на овим нашим просторима веран пратилац живота на овим нашим просторима, најбоље показује детаљ који нам говори о гостовању Горског вијенияа у Сомбору, када је пре почетка представе, Лаза Костић изговорио оду Хаџићу.

“Кад је на Цвети о.г. у Сомбору пред приказ Горског вијенияа А. Хаџић довршио свој увод којим је сомборском српском свету разјаснио важност и значај епохалнога Његошева дела, изненада се на позорници на челу изасланству месног позоришног одбора појави песник Лаза Костић и овим бираним речима поздрави А. Хаџића:

'Високопоштовани председниче,

Многоуважени управитељу,

Драги пријатељу!

Доносим ти две поруке, два поздрава.

Први је са онога света, од вечерашњег твога и нашега слављеника, песника Горског вијенца, владике Рада. И ноћас ми се јавио. Питам га, је ли му што криво, што си му, као што неки веле, тако немилостиво испрекидао, изломио, испресецао његов Горски вијенаи.

- Што велиш? - рече владика. - Изломио? Испресјеца? Не, ни да̂ Бог! Он је тек онако подвио неке пребрснате границе, заклонио неке прегусте увојке, да би се оно остало тим љевше приказало на онијем шедицама. Може се то коме и несвиђети, ал' што мари! Ја му гледам у срце те виђу, да му је била намјера као најљевша. Хвала му и поздрави га!

То ти је први поздрав.

Други ти поздрав доносим, са овом господом и браћом, од Сомбораца, твојих пријатеља и поштоватеља. Између твог пређашњег и садашњег доласка у Сомбор са нашом позоришном дружином, твојом највећом бригом и најмилијом пажњом, прошло је неких 40 година, од како си ти српски књижевник. Ми се сећамо вечерас, да је за то време твоје име записано на многој златној страници српске књиге, да је твоје име уткано у многу приложницу, увезено у многу илаштаницу на олтару српске просвете, да 
си ти за то време био углед и почетак свакој пристојности и питомини, сваком лепом обичају, вазда готов помоћи општој потреби својим смерним, прегорним, неразметљивим радом. Јер и осим позоришта, те златне књиге твога живота, осим просветног поља, твоја је угодљива нарав знала чинити добра. Користићу се својим драгоценим личним везама, својим пријатељима и знанцима на угледним местима у држави, ти си се навек трудио, да уклониш сваку размирицу, да помогнеш лепој слози између различитих племена у овој нашој лепој домовини, те си том својом тихом и благодетном радњом био не само на помоћи свом народу, него си угодио и целој држави.

Хвалећи Бога, што нам те је досад одржао тако здрава и крепка, молимо му се, да те још дуго поживи у тој снази и у тој лепој вољи. Живео!'

На то је А. Хаџић укратко захвалио за ту лепу пажњу и онда је почео приказ Горскога вијенца.

После представе приредили су Сомборци у част А. Хаџићу у великој дворници позоришног хотела свечан банкет, на којем су учествовале све угледне српске куће сомборске и цела позоришна дружина. Председник месног позоришног одбора др Давид Коњовић поздравио је веома лепо А. Хаџића, истакавши његове неувеле заслуге за наше народно позориште. У одздравици својој на ту здравицу захвалио је А. Хаџић дичним Сомборцима не лепом одзиву, којим су пратили рад народне позоришне дружине. За тим је проф. Мита Калић дигао чашу у здравље целе позоришне дружине па онда се ређале здравице све једна кићенија од друге. У раздрагану расположењу провели су честити Сомборци неколико угодних часова са својим милим гостима.

У Сомбору на велику среду 1902”. (Позориште, 1902: 101-102)

\section{Реч на крају:}

Реконструкција првог извођења Горског вијения на сцени Српског народног позоришта могућа је, захваљујући постојању првог позоришног листа на нашим просторима, листа Позориште. У време када се гасе позоришни листови, часописи, када нам периодика полако замире, повратак у прошлост, сто дванаест година уназад, уверава нас у неопходност постојања позоришних листова. Први позоришни лист зачео се у најстаријем професионалном театру код нас, 1871. 
године, Српском народном позоришту, десет година после његовог оснивања. Осим прецизне поделе, регистрованог времена и места извођења представе, у могућности смо да на страницама листа Позориште пронађемо све релевантне критике, које су исписивали прави књижевни и позоришни зналци, попут: Тихомира Остојића, Јована Храниловића, Милана Савића, Лазе Костића и други.

\section{Лumepamypa:}

(Горски вијенаи). (1902 ). Позориште. Нови Сад: бр. 3, 4. (17) јануар, 11. К.[Костић, Лаза]. (1902). (Са приказа «Горскога вијения»» у Сомбору). Позориште. Нови Сад: бр. 20, 20. април, 101-102.

О.[стојић], Тих.[омир]. (1902). О Горском вијенщу. Позориште. Нови Сад: бр. 14, 26. јануар, 56-59.

C-ћ.[авић], М. [илан]. (1902). Горски вијенаи. Позориште. Нови Сад: бр. 17, 31. јануар, 74-75.

(Свечана представа «Горског вијенияа). (1902). Позориште. Нови Сад: бр. 17, 31. јануар, 75-76.

Хр.[аниловић] Ј.[ован]. (1902). Српско народно позориште, Горски вијенаи. Позориште. Нови Сад: бр. 17, 31. јануар 1902, 73-74.

\section{The Mountain Wreath as the first theatre play in Novi Sad in 1902}

Abstract. The topic of this paper is The Mountain Wreath (Gorski vijenac) which was performed as the first play on the stage of the Serbian National Theatre in Novi Sad in 1902. There had been attempts at performing fragments of The Mountain Wreath in the years of 1896, 1897 and 1890. It is interesting that Radoje Domanović and his students had staged The Mountain Wreath in Vranje. On the occasion of the fiftieth anniversary of Petar Petrović Njegoš's death, The Mountain Wreath was performed as a whole night play. The timeless work of the great poet was adapted for stage by Antonije Hadžić. The prologue was written by poet Dr Laza Kostić, and the Apotheosis as the epilogue was written by the poet Jovan Živojinović. The music was composed and arranged by Isidor Bajić. All the preparations for the play, its performance, reception and Sombor tour was followed in the first theatre journal The Theatre, which was published by the oldest professional theatre in the region. The fundamental dilemma involved in staging The Mountain Wreath, which revolves around the question whether it is an epic or a drama, was addressed on a high theoretical level by Tihomir Ostojić in one of the 
texts that preceded the ceremonial performance. A theatre review was written on each performance of the play, so we can follow the reviews in the journal The Theatre by Jovan Hranilović, Milan Savić, the review transferred from the Vienac. Owing to the zealous chronicler of the theatre life, as the journal The Theatre was, we can also follow the ode Laza Kostić wrote to Antonije Hadžić during the Sombor tour.

Key words: theatre performance, epic, drama, The Mountain Wreath, the journal The Theatre, theatre review 